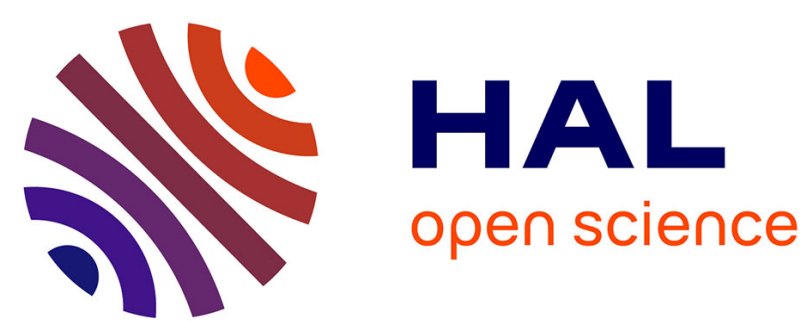

\title{
Influence of fine process particles enriched with metals and metalloids on Lactuca sativa L. leaf fatty acid composition following air and/or soil-plant field exposure
}

Eva Schreck, Christophe Laplanche, Marina Le Guédard, Jean-Jacques Bessoule, Annabelle Austruy, Tiantian Xiong, Yann Foucault, Camille Dumat

\section{To cite this version:}

Eva Schreck, Christophe Laplanche, Marina Le Guédard, Jean-Jacques Bessoule, Annabelle Austruy, et al.. Influence of fine process particles enriched with metals and metalloids on Lactuca sativa L. leaf fatty acid composition following air and/or soil-plant field exposure. Environmental Pollution, 2013, 179, pp.242-249. 10.1016/j.envpol.2013.04.024 . hal-00862290

\section{HAL Id: hal-00862290 https://hal.science/hal-00862290}

Submitted on 16 Sep 2013

HAL is a multi-disciplinary open access archive for the deposit and dissemination of scientific research documents, whether they are published or not. The documents may come from teaching and research institutions in France or abroad, or from public or private research centers.
L'archive ouverte pluridisciplinaire HAL, est destinée au dépôt et à la diffusion de documents scientifiques de niveau recherche, publiés ou non, émanant des établissements d'enseignement et de recherche français ou étrangers, des laboratoires publics ou privés. 


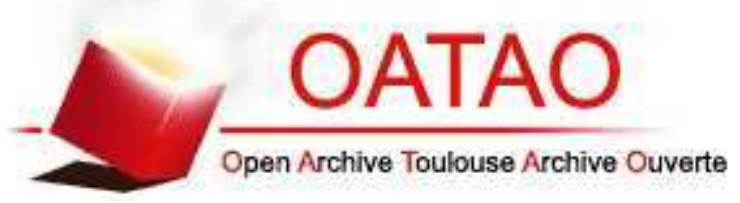

\section{Open Archive TOULOUSE Archive Ouverte (OATAO)}

OATAO is an open access repository that collects the work of Toulouse researchers and makes it freely available over the web where possible.

This is an author-deposited version published in : http://oatao.univ-toulouse.fr/ Eprints ID : 9383

To link to this article : DOI: 10.1016/j.envpol.2013.04.024

URL : http://dx.doi.org/10.1016/j.envpol.2013.04.024

To cite this version : Schreck, Eva and Laplanche, Christophe and Le Guédard, Marina and Bessoule, Jean-Jacques and Austruy, Annabelle and Xiong, Tiantian and Foucault, Yann and Dumat, Camille Influence of fine process particles enriched with metals and metalloids on Lactuca sativa L. leaf fatty acid composition following air and/or soilplant field exposure. (2013) Environmental Pollution, 179 . pp. 242249. ISSN 0269-7491

Any correspondance concerning this service should be sent to the repository administrator: staff-oatao@ listes-diff.inp-toulouse.fr 


\title{
Influence of fine process particles enriched with metals and metalloids on Lactuca sativa L. leaf fatty acid composition following air and/or soil-plant field exposure
}

\author{
Eva Schreck $^{\mathrm{a}, \mathrm{b}}$, Christophe Laplanche ${ }^{\mathrm{a}}$, Marina Le Guédard ${ }^{\mathrm{c}}$, Jean-Jacques Bessoule ${ }^{\mathrm{d}}$, \\ Annabelle Austruy ${ }^{\mathrm{a}}$, Tiantian Xiong ${ }^{\mathrm{a}}$, Yann Foucault ${ }^{\mathrm{a}, \mathrm{e}}$, Camille Dumat ${ }^{\mathrm{a}, *}$ \\ ${ }^{a}$ Université de Toulouse, INP, UPS, EcoLab (Laboratoire Ecologie Fonctionnelle et Environnement), ENSAT, Avenue de l'Agrobiopole, F-31326 Castanet \\ Tolosan, France \\ ${ }^{\mathrm{b}}$ Géosciences Environnement Toulouse (GET), Observatoire Midi Pyrénées, Université de Toulouse, CNRS, IRD, 14 Avenue E. Belin, F-31400 Toulouse, France \\ ${ }^{c}$ LEB Aquitaine Transfert-ADERA, F-33883 Villenave d'Ornon Cedex, France \\ ${ }^{\mathrm{d}}$ Université de Bordeaux, Laboratoire de Biogenèse Membranaire, UMR-5200, F-33883 Villenave d'Ornon Cedex, France \\ e STCM, Société de Traitements Chimiques des Métaux, 30 Avenue Fondeyre, 31200 Toulouse, France
}

Keywords:

Uptake pathways

Mixture of metal(loid)s

Leaf fatty acid composition

Statistical index

\begin{abstract}
We investigate the effect of both foliar and root uptake of a mixture of metal(loid)s on the fatty acid composition of plant leaves. Our objectives are to determine whether both contamination pathways have a similar effect and whether they interact. Lactuca sativa $\mathrm{L}$. were exposed to fine process particles enriched with metal(loid)s in an industrial area. Data from a first experiment were used to conduct an exploratory statistical analysis which findings were successfully cross-validated by using the data from a second one. Both foliar and root pathways impact plant leaf fatty acid composition and do not interact. Z index (dimensionless quantity), weighted product of fatty acid concentration ratios was built up from the statistical analyses. It provides new insights on the mechanisms involved in metal uptake and phytotoxicity. Plant leaf fatty acid composition is a robust and fruitful approach to detect and understand the effects of metal(loid) contamination on plants.
\end{abstract}

\section{Introduction}

Nowadays, as reported by Donisa et al. (2000) or Ma et al. (2010), atmospheric fallouts of fine particles enriched with metal(loid)s (denoted PM, in the present study) involve significant contaminations of ecosystem compartments: soils, organisms, ground and surface waters. The released metal(loid)s are highly persistent in the environment and can cause adverse effects for ecosystems and human health (Komárek et al., 2013). According to Bermudez et al. (2012), they can accumulate in vegetables and crops, with therefore health risks in relation with food chain contamination. Both soil-plant (Alexander et al., 2006; Polichetti et al., 2009) and air-plant (Perrone et al., 2010; Schreck et al., 2012a) transfers of inorganic pollutants are involved. Mechanisms of soil-plant (or root) transfers have been well studied for several years (Lin and Xing, 2007, 2008; Stampoulis et al., 2009; Ma et al.,

\footnotetext{
* Corresponding author.

E-mail address: camille.dumat@ensat.fr (C. Dumat).
}

2010; Yin et al., 2011; Lombi et al., 2011) whereas air-plant (or foliar) transfers have been scarcely investigated until recently (Uzu et al., 2010; Bermudez et al., 2011; Hu et al., 2011; Schreck et al., 2012a,b). Actually, the use of combined microscopy and spectroscopy techniques for tissue observations has brought some advances in the understanding of metal pathways (Schreck et al., 2012a). It has been demonstrated that metals can enter root cells: working on Cd particles, Isaure et al. (2006) reported that this metal is localized in vascular bundles of roots and coordinated to sulphur ligands, due to their high affinity with metallic element such as $\mathrm{Cd}$ or $\mathrm{Hg}$. Straczek et al. (2008) showed that Zn could have different localizations in roots: intracellular (bound with oxalate) or in the cell walls (linked to $\mathrm{COOH} / \mathrm{OH}$ groups) and finally bound to intracellular organic acids. Birbaum et al. (2010) reported that finest metallic particles may be incorporated into leaves, whereas large agglomerates are trapped on the surface wax. Depending on plant physiology or environmental factors, metals can cross the cuticle (Chamberlain, 1983; Ward and Savage, 1994; Nair et al., 2010; Uzu et al., 2010). After diffusion through the cuticle, ultrafine particles 
may interact with plant cells (Birbaum et al., 2010) and may be internalized during endocytosis process with phytotoxicity induced (Nair et al., 2010; Schreck et al., 2012a). Li et al. (2012) reported too that $\mathrm{Cd}$ exposure involve cellular changes such as modifications in photosynthetic pigments, electrolyte leakage, malondialdehyde (MDA) and antioxidants (ascorbic acid and glutathione) in Artemisia annua $\mathrm{L}$.

Phytotoxicity induced by inorganic pollutants was largely studied with the objective of health plants survey (Ait Ali et al., 2004; Ma et al., 2010; Violante et al., 2010). Moreover, in Europe, the development of biotests to highlight media quality is required by the Regulation on Registration, Evaluation, Authorisation and Restriction of Chemicals (REACH) as reported by Pereira et al. (2009), Bravin et al. (2010) and Schreck et al. (2011). Actually, the aims of REACH regulation are to ensure a high level of protection of human health and the environment from the risks caused by hazardous materials. Following plant exposure to metal(loid)s, the production of reactive oxygen species is observed, leading to oxidative damages on cellular components such as nucleic acids, proteins and especially lipids (Upchurch, 2008). Accordingly, the fatty acid composition of lettuce leaves is modified after exposure to soils polluted by metals (Le Guédard et al., 2008). A standardized foliar fatty acid ratio (C18:3/(C18:2 + C18:1 + C18:0)) is nowadays available to diagnose soil contamination by metals ex situ (AFNOR, 2012) and it was also successfully used in field (Le Guédard et al., 2012a,b). A decrease in the amount of tri-unsaturated fatty acids in higher plants was also observed for tomato seedlings grown in culture solution containing copper or cadmium (Ouariti et al., 1997; Djebali et al., 2005), as well as for pepper and rape seedlings grown in nutrient solution supplemented with Cd (Jemal et al., 2000; Ben Youssef, 2005). However, plants may be exposed to pollutants through both air and soil transfers (Sanitá di Toppi and Gabbrielli, 1999; Serbula et al., 2012). To our knowledge, foliar fatty acid composition has not been used so far to diagnose foliar metal uptake, whereas a global approach of plants exposure to metal(loid)s is necessary in order to better assess environmental and health risks (Dmuchowski et al., 2011).

In that scientific context, we intend to answer the following three main issues: does foliar metal(loid) uptake impact the leaf fatty acid composition? Do foliar and root pathways induce the similar phytotoxicity, in regards to fatty acid composition? Do the two transfer pathways interact? We finally aim to improve the knowledge on the mechanisms of metal(loid)s uptake and phytotoxicity. For that purpose, plants were exposed in situ in the immediate vicinity of metal processing company in order to investigate the impact of a complex mixture of metal(loid)s. The industrial study site is firstly described; two complementary field experiments were conducted via both foliar and root pathways. These experiments as well as chemical analyses (fatty acid composition and metal contents) are later described. Finally, statistical analyses explore and confirm relationships between variables and then allow presenting and discussing new insights on mechanisms of metal(loid) transfer and phytotoxicity.

\section{Materials and methods}

\subsection{Industrial site: smelter emissions and courtyard soil}

The industrial site chosen for the experimentation was a secondary lead smelter that recycles car batteries: the Society of Chemical Treatments of Metals (STCM, Schreck et al., 2012a,b). It is located in Toulouse, Southwest France in the peri-urban area $\left(43^{\circ} 38^{\prime} 12^{\prime \prime} \mathrm{N}, 01^{\circ} 25^{\prime} 34^{\prime \prime} \mathrm{E}\right)$. The rate of bulk atmospheric deposition was estimated to be about $325.2 \pm 12.8 \mathrm{mg} \mathrm{cm}^{-2}$ week ${ }^{-1}$, with $139.4 \pm 7.8 \mathrm{mg} \mathrm{cm}^{-2}$ week $^{-1}$ of lead, which is the most concentrated metal. The size of the particles from the channelled emissions of rotary furnaces was already determined: expressed as volume fractions, the majority of PM (89\%) was in the $1-100 \mu \mathrm{m}$ range, $7 \%$ were inferior to $1 \mu \mathrm{m}$ (sub-micronic and nanoparticles) and $4 \%$ were superior to $100 \mu \mathrm{m}$
(Uzu et al., 2011; Schreck et al., 2011). The STCM smelter emissions are assimilated to a mixture of various metals and metalloids. The major elements in the PM were, by mass: $\mathrm{Pb}(27 \%), \mathrm{O}(15 \%)$ and $\mathrm{S}(7.5 \%)$ with no significant differences according to particle size (Schreck et al., 2011). Several other secondary metals: Cd (2.5\%), Zn (0.5\%), Fe (0.1-0.4\%) and $\mathrm{Sb}(0.1 \%)$ were also present (Uzu et al., 2011). The remaining elements to complete $100 \%$ were for the most part $\mathrm{Cl}, \mathrm{Na}, \mathrm{C}$ and other metals such as $\mathrm{Al}, \mathrm{As}, \mathrm{Cu}$ and Ni recorded as traces. According to Uzu et al. (2009, 2011), particles are mainly composed of metallic sulphides, sulphates, oxides and perchlorates; lead

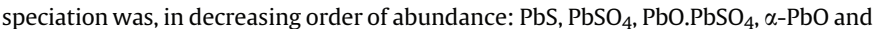
$\mathrm{Pb}^{0}$.

Industrial atmospheric fallouts in the smelter courtyard were measured using Owen gauges that enable wet and dry atmospheric depositions to be recorded (Taylor and Witherspoon, 1972; Gandois et al., 2010). Two gauges were left exposed throughout the entire experimental period in order to determine the metal(loid)s contents in atmospheric deposits (Schreck et al., 2012b), according to NF EN 14902 (2005).

In the smelter courtyard, the soils are largely polluted: the concentrations of lead vary from 100 to $39,000 \mathrm{mg} \mathrm{kg}^{-1}$ of soil according to the sampling sites (parking area, near the batteries storage area, proximity to an infiltration point, etc.). Thus, the soil chosen for the experimentation was sampled in a homogenous polluted zone (Foucault et al., 2013). Pb, Cd, Cu, Zn, As and Sb concentrations were respectively $1650 \pm 10.2,0.8 \pm 0.1,11.9 \pm 1.2,12.2 \pm 1.2,11.9 \pm 1.4$ and $86.8 \pm 3.2 \mathrm{mg} \mathrm{kg}-1$ of dry weight of soil. This historically polluted soil was sampled from the top $0-25 \mathrm{~cm}$ soil layer, air-dried at ambient temperature for a week, disaggregated and, finally, sieved to keep aggregates smaller than $2 \mathrm{~mm}$ before plant cultivation.

\subsection{Experimental set-up}

Two complementary field experiments were conducted by exposing lettuce (Lactuca sativa L.) to process particles. The first experiment (denoted $\mathrm{E}_{1}$ ) considered both foliar and root transfer whereas the second one (denoted $E_{2}$ ) focused only on foliar uptake. Lettuce (Lactuca sativa L.) was chosen for field exposure experiments $\left(E_{1}\right.$ and $E_{2}$ ), metal transfer and phytotoxicity studies. This leafy vegetable, largely consumed by humans (Lebeda et al., 2007), has been widely used as biotest to study soil-plant or air-plant transfers of metals (Waisberg et al., 2004; Alexander et al., 2006; Uzu et al., 2010; Schreck et al., 2012a) with in particular the measure of fatty acid composition in the context of polluted soils (Le Guédard et al., 2008; Le Guédard et al., 2012a,b).

For the experiment $E_{1}$, seed germination was carried out with commercial lettuce seeds (cultivar "Batavia Blonde dorée"), firstly immersed in a $10 \%$ sodium hypochloride solution for $10 \mathrm{~min}$ to ensure surface sterility (according to Lin and Xing, 2007; Schreck et al., 2011). After seed germination, young plants were then grown 15 days in a greenhouse on an uncontaminated or a polluted soil, according to the chosen exposure way in the experimental design: air and/or soil-plant uptake (see Fig. 1). Then, two-week-old plants were transferred in different individual pots each containing $4 \mathrm{~kg}$ of polluted or not polluted soil, accordingly to exposure experiments. A geotextile membrane was placed on the soil in view of avoiding direct transfer between air and soil in the experiment, as previously described by Uzu et al. (2010) and Schreck et al. (2012 a,b).

The design of the first experiment $\left(E_{1}\right)$ was reported in Fig. 1

The plants were segregated into 4 different batches to study the different transfer pathways and their potential interactions: (condition-1) no pollution or controls, (condition-2) soil pollution only, (condition-3) air pollution only and (condition-4) both air and soil pollutions. For conditions (1) and (2), plants were placed in a control area, without any atmospheric contamination. For conditions (3) and (4), plants were exposed to atmospheric fallouts enriched in metals, in the smelter courtyard.

Plant exposure was performed during 4 weeks and the influence of the way of transfer (foliar, root or the 2 both ways at once) was studied each week by determining fatty acid composition of plant leaves according to Le Guédard et al. (2008, 2012a,b), see Section 2.3 for details. Actually, six plants for each condition were dedicated to fatty acid composition analysis.

A second experiment $\left(E_{2}\right)$ focussing on foliar uptake was then performed: 30 plants of each condition (not exposed and exposed to atmospheric fallouts) were dedicated both to fatty acid composition and pollutant concentrations analysis as indicated in Fig. 1. Metal concentration in soil is provided elsewhere (Schreck et al., 2012b). Moreover, it's important to notice that during the whole of the second week of this foliar exposure experiment, the smelter activity was stopped (public holidays): PM was not emitted by the factory during this period.

\subsection{Fatty acid extraction, analysis and identification}

Both for $E_{1}$ and $E_{2}$ experiments, sampling consisted of fresh foliar tissue (between 20 and $200 \mathrm{mg}$, as reported by Le Guédard et al., 2012a,b) taken from the different lettuces grown on the industrial landfill or on the control area. Leaf samples were immediately placed in screw-capped tubes containing $1 \mathrm{ml}$ analytical grade methanol acidified with $2.5 \%$ (v/v) $\mathrm{H}_{2} \mathrm{SO}_{4}$ (Le Guédard et al., 2008; Le Guédard et al., 2012a,b). Samples were stored at $4{ }^{\circ} \mathrm{C}$ before analysis. 


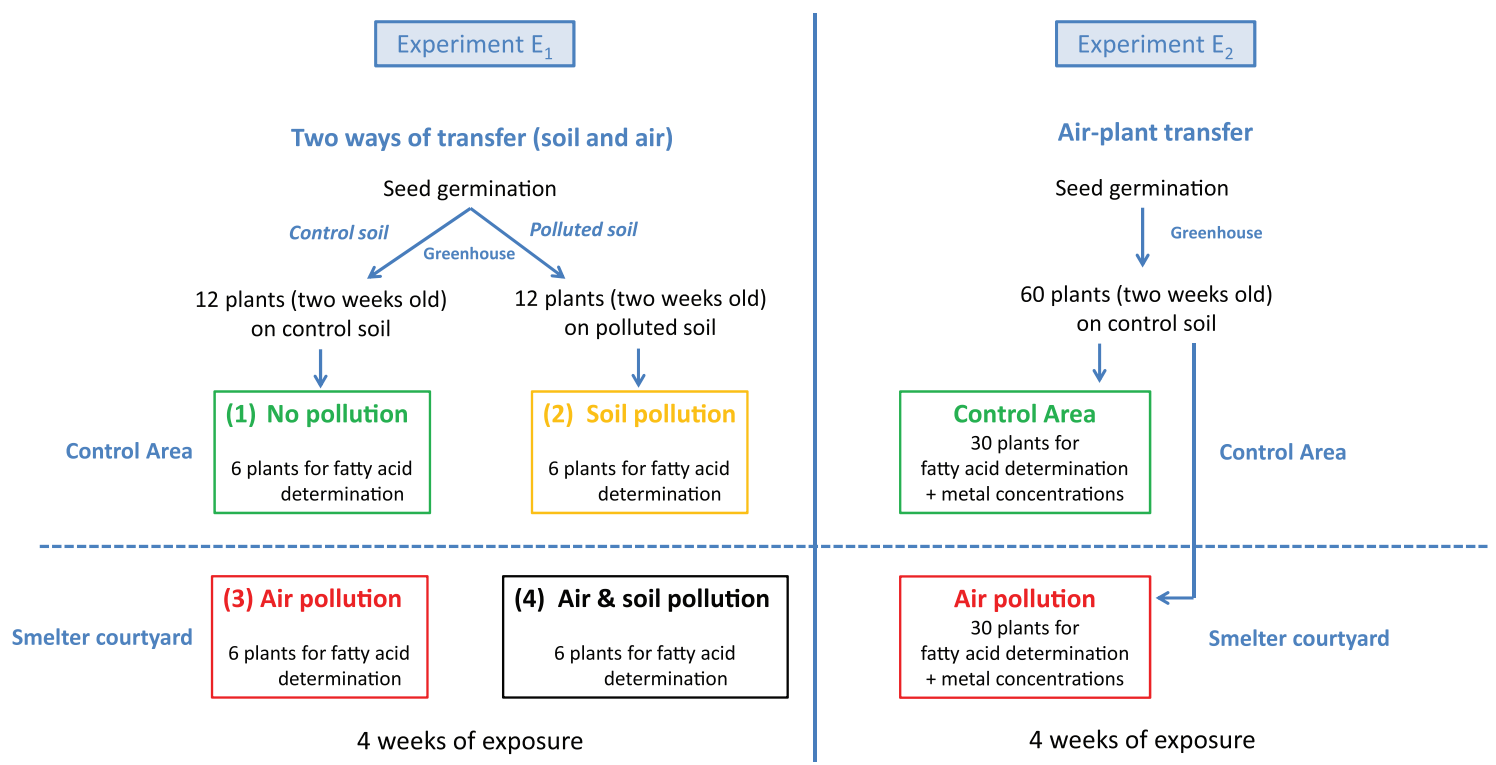

Fig. 1. Experimental design of the two complementary field experiments: $\mathrm{E}_{1}$ (exploratory analysis) and $\mathrm{E}_{2}$ (cross-validation).

Fatty acid analysis and identification was then performed according to Le Guédard et al. (2008, 2012a,b). Tubes containing the leaf samples in acidified methanol were heated to $80^{\circ} \mathrm{C}$ for $1 \mathrm{~h}$ and then cooled before adding $1.5 \mathrm{ml} \mathrm{H}_{2} \mathrm{O}$ and $0.75 \mathrm{ml}$ hexane. Fatty acid methyl esters (FAMEs) were extracted into hexane by vigorous shaking and a two-phase system was established by centrifugation ( $1500 \mathrm{~g}$ $5 \mathrm{~min}$ ). Separation of FAMEs in the hexane phase was performed by gas chromatography (Hewlett Packard 5890 series II) on a $15 \mathrm{~m} \times 0.53 \mathrm{~mm}$ Carbowax column (Alltech) with flame ionization detection and helium as carrier gas. The initial temperature of $160^{\circ} \mathrm{C}$ was held for $1 \mathrm{~min}$, followed by a $20^{\circ} \mathrm{C} \mathrm{min}^{-1}$ ramp to $190^{\circ} \mathrm{C}$ and a second ramp of $5{ }^{\circ} \mathrm{C} \mathrm{min}^{-1}-210^{\circ} \mathrm{C}$, and held for $6 \mathrm{~min}$. FAMES were identified by comparing their retention times with standards (Sigma Chemical, St. Louis, MO, USA).

\subsection{Metal concentration analysis}

For the $\mathrm{E}_{2}$ experiment, lettuce tissues were washed according to home-washing processes usually performed before consumption (Birbaum et al., 2010; Uzu et al., 2010; Schreck et al., 2012b) in order to focus on sanitary risk induced by ingestion of polluted vegetables. Each week, six samples of plant leaves were $72 \mathrm{~h}$ oven-dried at $40{ }^{\circ} \mathrm{C}$. Plant samples were mineralized with a Digiprep ${ }^{\circledR}$ instrument from SCP Science producer. $0.125 \mathrm{~g}$ of each plant sample was digested by $5 \mathrm{ml}$ of aqua regia (mixture of $1 / 4 \mathrm{HNO}_{3}$ and $3 / 4 \mathrm{HCl}$ ) $+2 \mathrm{ml}$ of $\mathrm{H}_{2} \mathrm{O}_{2}$ at $55^{\circ} \mathrm{C}$ for $25 \mathrm{~min}$ and then at $80{ }^{\circ} \mathrm{C}$ for $4 \mathrm{~h}$. After dilution in ultra-pure water and syringe filtration $(0.45 \mu \mathrm{m})$, the $\mathrm{Pb}, \mathrm{Cd}, \mathrm{Cu}, \mathrm{Zn}, \mathrm{As}$ and $\mathrm{Sb}$ concentrations were measured by inductively coupled plasma-optical emission spectrometry ICP-OES (IRIS Intrepid II XXDL) or inductively coupled plasma-mass spectrometry ICP-MS (X Series II, Thermo Electron) accordingly to concentrations. Ten blanks were submitted to the same treatment (mineralization and assay) for control. Each sample was analysed in triplicate. The detection limits for $\mathrm{Pb}, \mathrm{Cd}, \mathrm{Cu}, \mathrm{Zn}$, As and Sb were $0.3,0.2,1.3,2.2,0.2$ and $0.2 \mu \mathrm{g} \mathrm{I}^{-1}$, respectively, whereas the limits of quantification were $0.4,0.3,2,3,0.3$ and $0.4 \mu \mathrm{g} \mathrm{l} \mathrm{l}^{-1}$, respectively. The accuracy of measurements was checked using reference materials: Virginia tobacco leaves, CTA-VTL-2, ICHTJ and TM-26.3 certified reference material from the National Water Research Institute, Canada. The concentrations found were within $97-101 \%$ of the certified values for all measured elements (Schreck et al. 2012a).

During all the time of the experiment, potential variations of metals concentrations in soil were checked according to the following procedure: metal(loid)s total concentrations were measured by ICP-OES (IRIS Intrepid II XXDL) after mineralization in aqua regia according to ISO $1146627\left(\mathrm{HNO}_{3} 65 \%, \mathrm{HCl} 37 \%\right.$, ratio $3: 1$ $\mathrm{v} / \mathrm{v}$ ). Detection limits were below $100 \mu \mathrm{g} \mathrm{l}^{-1}$ in ICP-OES analysis and analytical errors less than $5 \%$.

As reported in a previous published study (Schreck et al., 2012b) and as reissued in Supplementary material S1, metal(loid)s contents were significantly higher for exposed lettuces than for the lettuces grown in the uncontaminated areas.

\subsection{Statistical data analysis}

Exploratory statistical analysis is conducted by using data from the $\mathrm{E}_{1}$ experiment. Data from the $E_{2}$ experiment will be used to cross-validate findings of the exploratory analysis.

There are 18 different treatments in the $\mathrm{E}_{1}$ experiment (Fig. 1) depending on the duration of exposure $(0,1,2,3,4$ weeks) and the contamination pathway (control, air only, soil only, air and soil). Such treatments can be defined by using the three-level cross-factor duration of exposure $\times$ air pathway (not exposed, exposed) $\times$ soil pathway (not exposed, exposed). Factors duration of exposure, air pathway, and soil pathway are denoted in a more concise manner Duration, Air, and Soil in the following. The significance of the effect of treatment on fatty acid contents is investigated by the use of a 3-way MANOVA. Isolated factors (Duration, Air, and Soil) as well as two-factor (Air $\times$ Soil, Air $\times$ Duration, Soil $\times$ Duration) and three-factor (Air $\times$ Soil $\times$ Duration) interactions are considered.

Patterns in variations of fatty acid concentrations with respect to treatment are explored by the use of a Linear Discriminant Analysis (LDA). Generally speaking, LDA computes linear combinations of the original variables which maximize the potential to distinguish presupposed known groups - by optimizing the ratio of between-group to within-group sums of squares. Similarly to Principal Component Analysis (PCA), LDA eigenvalues are ratios of between-group to within-group sums of squares and LDA eigenvectors are weights of the linear combinations (Venables and Ripley, 2010). In our case, LDA computes linear combinations of fatty acid contents (C16:0, C16:1, C18:0, C18:1, C18:2, C18:3) with treatment as a grouping factor. Data samples are later projected onto LDA eigenvectors, referred to in the following as LDA outputs (denoted $\mathrm{Y}_{1}$ up to $\mathrm{Y}_{6}$ ). LDA eigenvalues are normalized with respect to the sum of all 6 LDA eigenvalues, later referred to as proportions of explained variances for each discriminant. The significance of the effect of treatment on fatty acid contents is investigated by the use of 3-way ANOVAs (Kutner et al., 2004) on each LDA outputs.

Actually, fatty acid contents are transformed before being provided to the LDA. The choice of the transformation is guided by the use of the Box-Cox transformation procedure (Box and Cox, 1964), which encompasses power transformations (of power $\lambda \neq 0$ ) and the log-transform ( $\lambda=0$ by definition). The main interest of using a transformation is to stabilize the variance across treatments (homoscedasticity) and reach marginal normality. LDA computations as well as ANOVA parametric testing indeed require that observations form a random sample which is normally distributed and homoscedastic. Assumptions of normality and homoscedasticity are checked by using Shapiro-Wilk and Brown-Forsythe tests, respectively. Pairwise comparisons between treatments are achieved by using Tukey Honest Significant Difference (HSD) tests.

There are 8 different treatments in the $\mathrm{E}_{2}$ experiment (Fig. 1) depending on the duration of exposure (1,2,3 or 4 weeks) and the contamination pathway (control or air only). The significance of the effect of treatment on fatty acid contents is investigated by the use of 2-way ANOVA (factors Duration, Air and Air $\times$ Duration). Assumptions of normality and homoscedasticity as well as pairwise comparisons are computed as described earlier. Statistical computations are carried out with $\mathrm{R}$ software (R Core Team, 2012).

\section{Results and discussion}

\subsection{Fatty acid composition in lettuce leaves across treatments}

Fatty acid compositions in lettuce leaves following the $E_{1}$ experiment are shown in Table 1 . It firstly appears that after two weeks in the green-house (under monitored conditions), lettuces 
Table 1

Fatty acid composition (mean \pm standard deviation) across treatments for experiment $\mathrm{E}_{1}$. There are 6 replicates per treatment, except for treatment air at 4 weeks ( 5 replicates).

\begin{tabular}{|c|c|c|c|c|c|c|c|}
\hline Treatment & Duration (week) & C16:0 (\%) & C16:1 (\%) & C18:0 (\%) & C18:1 (\%) & C18:2 (\%) & $\mathrm{C} 18: 3(\%)$ \\
\hline Control & 0 & $19.6 \pm 4.1$ & $2.8 \pm 0.9$ & $1.5 \pm 0.4$ & $1.8 \pm 0.7$ & $17.9 \pm 2.8$ & $56.3 \pm 5.7$ \\
\hline Control & 1 & $24.2 \pm 1.4$ & $3.2 \pm 0.5$ & $1.8 \pm 0.2$ & $1.6 \pm 0.3$ & $14.7 \pm 1.1$ & $54.5 \pm 1.5$ \\
\hline Control & 2 & $22.1 \pm 1.4$ & $3.2 \pm 0.3$ & $1.8 \pm 0.6$ & $1.6 \pm 0.3$ & $17.5 \pm 2.4$ & $53.8 \pm 2.4$ \\
\hline Control & 3 & $23.0 \pm 1.5$ & $3.9 \pm 0.5$ & $1.9 \pm 0.4$ & $1.4 \pm 0.4$ & $20.6 \pm 3.5$ & $49.3 \pm 3.2$ \\
\hline Control & 4 & $25.0 \pm 1.6$ & $3.4 \pm 0.5$ & $2.4 \pm 0.4$ & $2.2 \pm 0.3$ & $20.8 \pm 2.7$ & $46.2 \pm 2.2$ \\
\hline Soil & 0 & $21.5 \pm 2.2$ & $2.7 \pm 0.2$ & $1.8 \pm 0.1$ & $2.4 \pm 0.3$ & $18.0 \pm 2.2$ & $53.5 \pm 3.3$ \\
\hline Soil & 1 & $22.3 \pm 1.0$ & $2.1 \pm 0.3$ & $1.8 \pm 0.2$ & $1.7 \pm 0.2$ & $15.0 \pm 1.3$ & $57.1 \pm 1.7$ \\
\hline Soil & 2 & $22.9 \pm 1.2$ & $2.6 \pm 0.3$ & $1.5 \pm 0.2$ & $1.4 \pm 0.2$ & $15.7 \pm 1.2$ & $55.8 \pm 1.2$ \\
\hline Soil & 3 & $23.8 \pm 1.4$ & $3.5 \pm 0.2$ & $2.0 \pm 0.5$ & $1.6 \pm 0.3$ & $18.8 \pm 2.4$ & $50.5 \pm 1.6$ \\
\hline Soil & 4 & $23.5 \pm 2.7$ & $3.2 \pm 0.8$ & $1.9 \pm 1.3$ & $1.8 \pm 1.2$ & $19.6 \pm 3.4$ & $50.0 \pm 3.7$ \\
\hline Air & 1 & $21.9 \pm 1.4$ & $2.2 \pm 0.4$ & $2.0 \pm 0.3$ & $1.6 \pm 0.4$ & $16.0 \pm 0.9$ & $56.4 \pm 2.5$ \\
\hline Air & 2 & $22.6 \pm 1.0$ & $2.8 \pm 0.2$ & $2.0 \pm 0.1$ & $1.5 \pm 0.4$ & $17.4 \pm 0.9$ & $53.7 \pm 0.8$ \\
\hline Air & 3 & $23.2 \pm 0.5$ & $3.3 \pm 0.8$ & $2.2 \pm 0.3$ & $1.4 \pm 0.3$ & $20.2 \pm 1.5$ & $49.7 \pm 1.7$ \\
\hline Air & 4 & $22.9 \pm 1.1$ & $3.5 \pm 0.6$ & $2.9 \pm 0.6$ & $2.2 \pm 0.5$ & $19.9 \pm 3.6$ & $48.5 \pm 3.2$ \\
\hline Soil \& Air & 1 & $20.8 \pm 5.0$ & $1.7 \pm 1.9$ & $2.0 \pm 0.6$ & $1.9 \pm 0.7$ & $15.3 \pm 0.9$ & $58.2 \pm 8.1$ \\
\hline Soil \& Air & 2 & $22.8 \pm 0.5$ & $1.9 \pm 0.5$ & $2.2 \pm 0.5$ & $1.6 \pm 0.3$ & $15.0 \pm 2.5$ & $56.4 \pm 3.0$ \\
\hline Soil \& Air & 3 & $23.5 \pm 1.8$ & $2.9 \pm 0.9$ & $2.1 \pm 0.4$ & $1.8 \pm 0.3$ & $18.5 \pm 2.4$ & $51.3 \pm 3.4$ \\
\hline Soil \& Air & 4 & $23.6 \pm 4.2$ & $2.9 \pm 1.2$ & $2.5 \pm 0.6$ & $1.9 \pm 1.0$ & $18.6 \pm 3.7$ & $50.7 \pm 7.0$ \\
\hline
\end{tabular}

having grown on the contaminated soil did not display a significant lower $\mathrm{C} 18: 3 /(\mathrm{C} 18: 2+\mathrm{C} 18: 1+\mathrm{C} 18: 0)$ ratio $(2.61 \pm 0.1)$ than seedlings having grown on the control soil $(2.70 \pm 0.5)$. In addition, it also appears that after an additional (from 1 to 4 week) exposure, this ratio did not significantly decrease in the presence of soil and/ or air contaminants. This indicates that in comparison with our previous studies (Le Guédard et al., 2008; AFNOR, 2012; Le Guédard et al., 2012a,b), following the $\mathrm{E}_{1}$ experiment, the effect of contaminants did not induce a huge oxidative stress. Hence, in comparison with these previous studies, a more thorough statistical analysis of the results was required to determine whether the lettuce fatty acid composition was significantly affected by the soil and/or air field exposures to inorganic pollutants.

\subsection{Statistical determination of a parameter to predict the impact on lipid composition of plant exposure to metals and metalloids}

Fatty acid composition is variable across treatments, as confirmed by the results of the 3-way MANOVA (Table 2). Isolated factors (Duration, Air and Soil) have significant effects on fatty acid compositions. No interaction term is significant. The consequences of the latter assertion are that: (1) both air and soil metal contaminations have a significant effect on fatty acid composition and (2) soil and air pathways do not interact; they have non-synergetic and non-antagonist effects.

Fatty acid concentrations are log-transformed, as indicated by the results of the Box-Cox procedure (95\% confidence intervals of $\lambda$ for all 6 fatty acid variables are included within $[-0.25,0.25]$ ), before being provided to the LDA. The proportions of explained variances are $82.32,9.03,3.22,3.02,1.55$, and $0.86 \%$ on each discriminant. Eigenvectors are provided in Table 3. The projection of data samples on the first two eigenvectors is illustrated in Fig. 2.

As illustrated in Fig. 2, the LDA efficiently discriminates treatment. More specifically, the first component substantially discriminates duration of exposure $\left(\mathrm{Y}_{1}\right.$ increases with the duration of exposure) and the second component discriminates contamination pathway (Control $>$ Soil $>$ Air $>$ Soil \& Air). Such assessments are substantiated by the results of 3-way ANOVAs on LDA outputs. Significance of isolated factors (Duration, Air and Soil) as well as two-factor and three-factor interactions is provided in Table 2. Results of normality (Shapiro-Wilk) and homoscedasticity (Brown-Forsythe) tests are also provided. Results show that residual variance is equal across treatments. Residual variance is normally distributed for variables $\mathrm{Y}_{2}-\mathrm{Y}_{5}$. Isolated factors (Duration, Air and Soil) have significant effects on variables $\mathrm{Y}_{1}-\mathrm{Y}_{6}$ (depending on the variable) and no interaction is significant. ANOVA results also show that $Y_{1}$ substantially discriminates duration of exposure better than the other LDA output variables and that $Y_{2}$ better discriminates contamination pathway. Given that we are more interested in discriminating pathway than duration of exposure, we now focus in the following on the second discriminant:

$$
\begin{aligned}
\mathrm{Y}_{2}= & -11.97 \log _{10}(\mathrm{C} 16: 0)+12.03 \log _{10}(\mathrm{C} 16: 1) \\
& -7.12 \log _{10}(\mathrm{C} 18: 0)+3.02 \log _{10}(\mathrm{C} 18: 1) \\
& -2.76 \log _{10}(\mathrm{C} 18: 2)+6.85 \log _{10}(\mathrm{C} 18: 3)
\end{aligned}
$$

Which is approximately equal to $12 \log _{10}(\mathrm{Z})$ with:

$$
\mathbf{Z}=\left(\frac{\mathbf{C} 16: \mathbf{1}}{\mathbf{C 1 6 : 0}}\right) \times\left(\frac{\mathbf{C} 18: \mathbf{3}}{\mathbf{C 1 8 : 0}}\right)^{0.57} \times\left(\frac{\mathbf{C 1 8}: \mathbf{1}}{\mathbf{C 1 8 : 2}}\right)^{0.23}
$$

Table 2

$P$-values of the tests of the 3-way MANOVA (first column) and the 3-way ANOVAs (remaining columns) which connects fatty acid compositions to treatment factors. Factors are

\begin{tabular}{|c|c|c|c|c|c|c|c|}
\hline & All & $\mathrm{Y}_{1}$ & $\mathrm{Y}_{2}$ & $\mathrm{Y}_{3}$ & $\mathrm{Y}_{4}$ & $\mathrm{Y}_{5}$ & $\mathrm{Y}_{6}$ \\
\hline Shapiro-Wilk & & $0.000261 * * *$ & 0.088967 & 0.096404 & 0.798294 & 0.086378 & $0.000001^{* * *}$ \\
\hline Brown-Forsythe & & 0.256905 & 0.687362 & 0.355252 & 0.176096 & 0.235837 & 0.635610 \\
\hline Air & $0.000000 * * *$ & $0.000440^{* * *}$ & $0.000000 * * *$ & 0.517100 & $0.019562 *$ & 0.095651 & 0.953333 \\
\hline Soil & $0.000208^{* * *}$ & $0.007499 * *$ & $0.001148^{* *}$ & 0.659816 & $0.001101^{* *}$ & 0.821149 & 0.265321 \\
\hline Duration & $0.000000^{* * *}$ & $0.000000 * * *$ & $0.000602 * * *$ & $0.000411^{* * *}$ & 0.204252 & 0.490537 & 0.900101 \\
\hline Air $\times$ Soil & 0.664049 & 0.392292 & 0.175658 & 0.925690 & 0.302537 & 0.434128 & 0.850495 \\
\hline Air $\times$ Duration & 0.305683 & 0.230966 & 0.148068 & 0.494705 & 0.479763 & 0.263779 & 0.401577 \\
\hline Soil $\times$ Duration & 0.126004 & 0.244480 & 0.051573 & 0.097686 & 0.321773 & 0.656440 & 0.451030 \\
\hline Air $\times$ Soil $\times$ Duration & 0.591404 & 0.061734 & 0.196718 & 0.882762 & 0.818391 & 0.373761 & 0.984920 \\
\hline
\end{tabular}
air, soil, duration, and interactions and dependent variables of the ANOVAs are LDA linear combinations of fatty acid contents (C16:0, C16:1, C18:0, C18:1, C18:2, C18:3) which are denoted $\mathrm{Y}_{1}-\mathrm{Y}_{6}$. P-values of tests for normality (Shapiro-Wilk) and homoscedasticity (Brown-Forsythe) are also provided (Significance codes: $<0.001$ '***', $<0.01{ }^{* * *},<0.01$ “*”, $<0.05$ “’). 
Table 3

Proportions of explained variances and coordinates of the eigenvectors of the LDA.

\begin{tabular}{lrrrrrr}
\hline Discriminant & \multicolumn{1}{l}{1} & \multicolumn{1}{l}{ 2} & \multicolumn{1}{l}{4} & \multicolumn{1}{l}{5} \\
\hline $\log _{10}(\mathrm{C} 16: 0)$ & -0.28 & -11.97 & -6.85 & 8.44 & 19.75 & -2.50 \\
$\log _{10}(\mathrm{C} 16: 1)$ & -4.24 & 12.03 & -1.42 & -2.62 & -4.06 & -5.78 \\
$\log _{10}(\mathrm{C} 18: 0)$ & 1.78 & -7.12 & 2.48 & -9.26 & -4.22 & -4.72 \\
$\log _{10}(\mathrm{C} 18: 1)$ & -3.05 & 3.02 & 3.84 & 9.52 & -2.77 & -1.27 \\
$\log _{10}(\mathrm{C} 18: 2)$ & 5.62 & -2.76 & 8.99 & -6.53 & 10.07 & 9.35 \\
$\log _{10}(\mathrm{C} 18: 3)$ & -6.49 & 6.85 & -6.23 & -1.22 & -16.97 & 4.04 \\
Proportion (\%) & 82.32 & 9.03 & 3.22 & 3.02 & 1.55 & 0.86 \\
\hline
\end{tabular}

$Z$ values are of equal spread for all treatments, no matter the duration and the contamination pathway. Values of $Z$ across treatments are illustrated in Fig. 3. The $\mathrm{Z}$ quantity has the three following compelling properties. $\mathrm{Z}$ is the product of three fatty acid concentration ratios (C16:1/C16:0, C18:3/C18:0, and C18:1/ C18:2) with different weights (1, 0.57 , and 0.23 respectively). This property will be used later when exploring the relationships between uptake and phytotoxicity. $\mathrm{Z}$ is a dimensionless quantity which values are in our experiments comprised between 0 and 1 . The latter property will be of interest in order to compare $Z$ values across treatments and across experiments. Finally, $\mathrm{Z}$ is normally distributed and of equal variance across the 18 groups (ShapiroWilk: $p=0.35$; Brown-Forsythe: $p=0.58$ ). Consequences are facilitated subsequent statistical parametric testing. Three-way ANOVA results show that isolated factors (Air, Soil, and Duration) have significant effects on $Z$, and no interaction is significant (Table 4). Values of the $Z$ quantity across treatments are illustrated in Fig. 3. Values of the three ratios C16:1/C16:0, C18:3/C18:0, and C18:1/C18:2 are illustrated in Supplementary Material S2 and significance of ANOVA testings with respect to treatment factors are provided in Table 4 .
3.3. Interactions between metals uptake and fatty acids of Lactuca sativa L. leaf membranes: a new way to explore relationship between uptake and phytotoxicity

We mention above that oxidative stress very likely did not occur in plants during $E_{1}$ experiment. In agreement, the fatty acid ratio with the most important weight in $Z$ values is the $C 16: 1 / C 16: 0$ ratio, and it is generally admitted that mono-unsaturated fatty acids are not targets of oxidative stress as reported by Cipak et al. (2006, 2008). C16:1 fatty acid in leaves is (almost) exclusively associated with thylakoid phosphatidylglycerol (PG), and the absence of this unsaturated fatty acid associated with this phospholipid may impact photosynthesis activity (Ivanov et al., 2012). Hence, Z parameter formula suggests that process particles, carrying a mixture of metal(loid)s, initially induce an early alteration on chloroplast membranes, whatever the way of uptake involved (airleaf or soil-root pathway), and could lead later to the disruption of photosynthetic function, finally involving phytotoxicity (Kobayashi et al., 2007; Aronsson et al., 2008).

C16:1 fatty acid in leaves is synthesized from C16:0 (associated with PG) by a plastidial fatty acid desaturase. Hence, it appears that the simplest explanation for the weight of the $\mathrm{C} 16: 1 / \mathrm{C} 16: 0$ ratio in $\mathrm{Z}$ values is to assume that this desaturase is inhibited by metal uptake. Actually we focused on week 1 and week 2 (highest differences in $\mathrm{Z}$ values), and we considered, in the absence of contaminants, that for 1000C16:0 synthesized molecules, 32 molecules of C16:1 were synthesized, and that $76.5 \%$ of the remaining C16:0 molecules were elongated to synthesize C18:0. We also considered that $97.6 \% ; 97.7 \%$ and $77 \%$ of $\mathrm{C} 18: 0, \mathrm{C} 18: 1 ; \mathrm{C} 18: 2$ were desaturated to form C18:1, C18:2 and C18:3 respectively. These assumptions lead to the following fatty acid composition: $22.7 \%$; $3.2 \% ; 1.8 \% ; 1.7 \%$; $16.2 \%$ and $54.4 \%$ of $\mathrm{C} 16: 0 ; \mathrm{C} 16: 1 ; \mathrm{C} 18: 0 ; \mathrm{C} 18: 1, \mathrm{C} 18: 2$ and $\mathrm{C} 18: 3$ respectively (supplementary material S3), closed to the

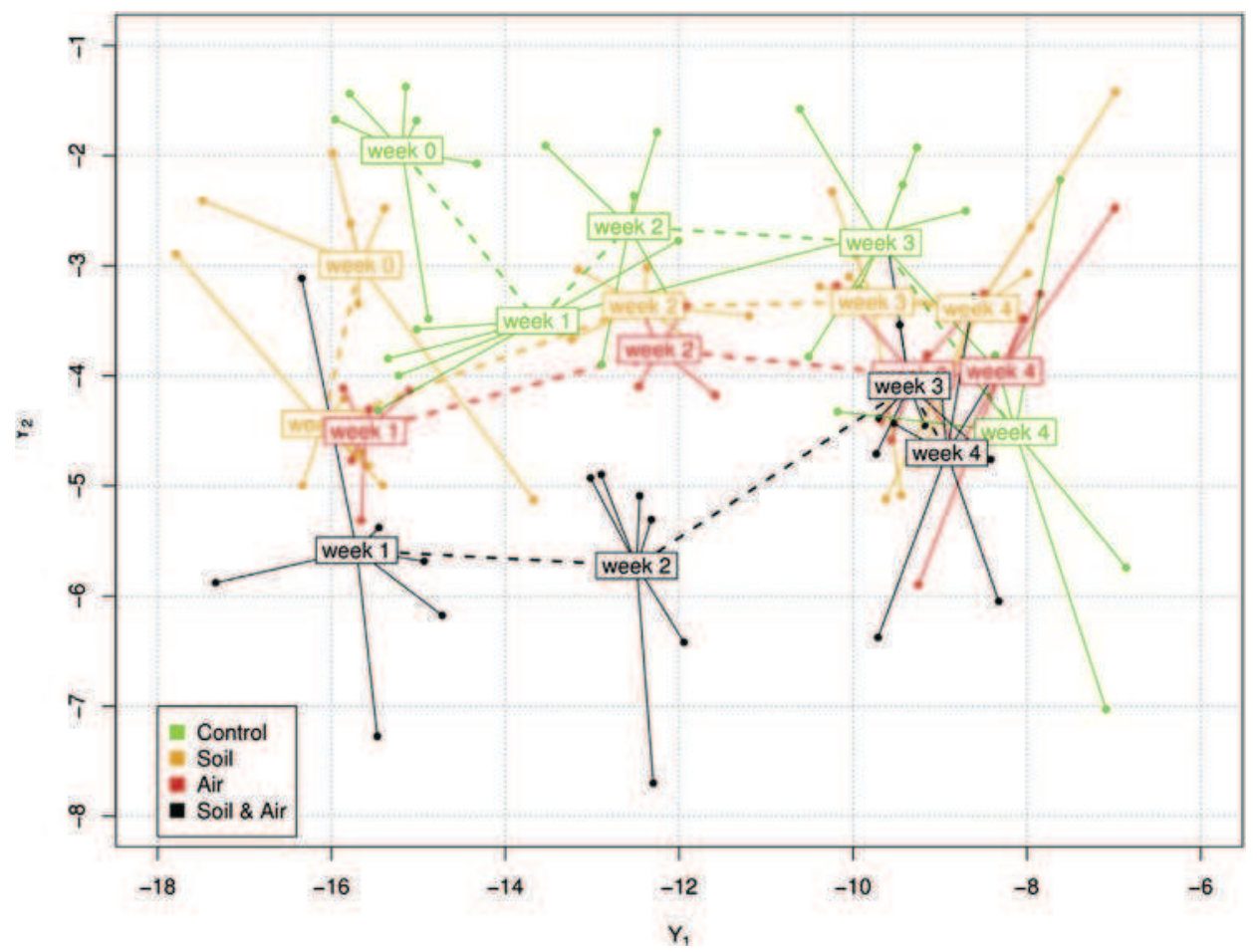

Fig. 2. Projection of samples on the first two LDA eigenvectors for $E_{1}$ experiment. 


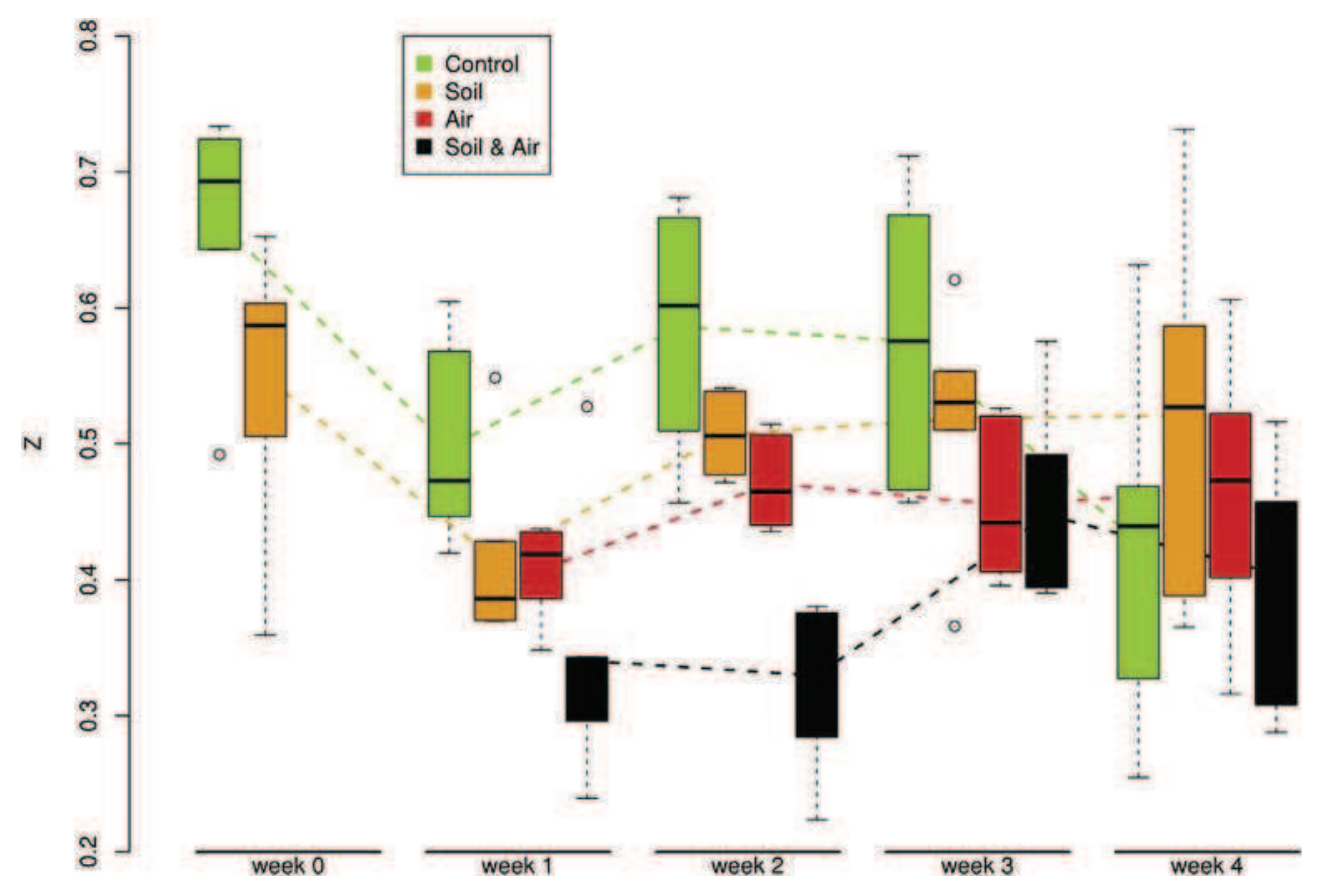

Fig. 3. Box-and-whisker plots of $Z$ parameter across treatments for $E_{1}$ experiment.

experimental values shown in Table 1 for weeks 1 and 2 in the absence of pollutants. By assuming that both air and soil contaminants inhibited by $25 \%$ the desaturation of C16:0 molecules, and that there was an additive effect of soil and air contaminants, we obtained $0.59 ; 0.43 ; 0.43$ and 0.32 for $Z$ values in the absence and in the presence of soil, air, and both soil and air contaminants respectively. This illustrates the heavy weight of the C16:1/C16:0 ratio in $Z$ value.

The appearance of $\mathrm{C} 18: 3 / \mathrm{C} 18: 0$ and $\mathrm{C} 18: 1 / \mathrm{C} 18: 2$ in $\mathrm{Z}$ calculations could be explained by a very slight effect of air pollution (only) on the C18:0 desaturation (96.3\% instead of $96.7 \%$ of $\mathrm{C} 18: 0$ desaturated), and by a very slight effect of soil pollution (only) on the C18:2 desaturation (78.5\% instead of $77 \%$ of $\mathrm{C} 18: 2$ desaturated). This leads to $0.59 ; 0.45 ; 0.41$ and 0.31 for $Z$ values in the absence and in the presence of soil, air, and both soil and air contaminants respectively, and the resulting fatty acid compositions indicated are closed to the experimental values shown in Table 1 for week 1 and 2 in the absence and in the presence of pollutants (Supplementary Material S3).

All of these data explain why both air and soil metal contaminations have various significant (Table 4) effects on the various fatty acid ratio, while they have non-synergistic and non-antagonist effects.

\subsection{Leaf fatty acid composition in lettuce shoots following foliar $E_{2}$ exposure}

The soundness of the potential use of the $\mathrm{Z}$ parameter to evidence air pollution is assessed by using data from the second experiment $\left(E_{2}\right)$. Fatty acid composition across treatments is provided in Table 5 and $Z$ values are illustrated in Fig. 4. Results of normality, homoscedasticity, and ANOVA tests show that $\mathrm{Z}$ is still normally distributed ( $p=0.304335)$ and of equal variance across treatments $(p=0.078323)$. Both Air and Duration have a significant effect on Z (Air, $p=0.009904^{* *}$; Duration, $p=0.834278$; Air $\times$ Duration, $\left.p=0.000045^{* * *}\right)$.

Differences between control and exposed are not significant at week $1(p=0.9999)$ and week $2(p=0.1958)$. Differences are significant at week $3\left(p=0.01663^{*}\right)$ and week $4\left(p=0.0032^{* *}\right)$ and, similar to what has been found regarding the $\mathrm{E}_{1}$ experiment, $\mathrm{Z}$ is lower for contaminated plants. In addition, it can be noted that looking at the control experiments (ie. in the absence of contaminants) the changes in the fatty acid composition as a function of time (a decrease in 18:3) observed following the $E_{1}$ experiment were not observed in $E_{2}$. This is likely because light, temperature and/or humidity were not the same, but we are unable to demonstrate it (it was not the aim of the present study, and the experiments were not designed to study this point). Nevertheless, this observation strengthens the $\mathrm{Z}$ because despite these differences, this parameter made it possible to evidence adverse effects of pollutants following both $E_{1}$ and $E_{2}$ experiments.

Schreck et al. (2012b) have shown a high foliar uptake of metals (reissued in Supplementary material S1). As mentioned above, in the present experiment, emissions from plant was stopped during week number 2 with a subsequent reduction of PM fallouts, and the stop in smelter activity was therefore also observed as a break in metal uptake by plant. Hence following the $E_{2}$ experiment, it appears that the $\mathrm{Z}$ which has been defined earlier is efficient in

Table 4

$P$-values of the tests of the 3-way ANOVAs which dependent variables are fatty acid ratios $(\mathrm{Z}, \mathrm{C} 16: 1 / \mathrm{C} 16: 0, \mathrm{C} 18: 3 / \mathrm{C} 18: 0$, and $\mathrm{C} 18: 1 / \mathrm{C} 18: 2)$ and which factors are the treatments (Air, Soil, Duration, and interactions). $P$-values of the normality (Shapiro-Wilk) and homoscedasticity (Brown-Forsythe) tests are also provided (Sig-

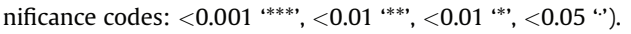

\begin{tabular}{lllll}
\hline & $\mathrm{Z}$ & $\mathrm{C} 16: 1 / \mathrm{C} 16: 0$ & $\mathrm{C} 18: 3 / \mathrm{C} 18: 0$ & $\mathrm{C} 18: 1 / \mathrm{C} 18: 2$ \\
\hline Shapiro-Wilk & 0.352496 & $0.007205^{* *}$ & 0.262648 & 0.000440 \\
Brown-Forsythe & 0.580434 & $0.232108^{* * *}$ & 0.470564 & 0.395297 \\
Air & $0.000000^{* * *}$ & $0.001366^{* *}$ & $0.000532^{* * * *}$ & 0.931948 \\
Soil & $0.000964^{* * *}$ & $0.000013^{* * *}$ & 0.319973 & $0.012494^{*}$ \\
Duration & $0.000185^{* * *}$ & $0.000000^{* * *}$ & $0.000004^{* * *}$ & $0.000049^{* * *}$ \\
Air $\times$ Soil & 0.535369 & 0.420212 & 0.810316 & 0.380353 \\
Air $\times$ Duration & 0.201538 & 0.274224 & 0.751036 & 0.991581 \\
Soil $\times$ Duration & 0.061689 & 0.756881 & 0.212121 & 0.145309 \\
Air $\times$ Soil $\times$ Duration & 0.182960 & 0.478196 & 0.694727 & 0.948414 \\
\hline
\end{tabular}


Table 5

Fatty acid composition (mean \pm standard deviation) across treatments for experiment $\mathrm{E}_{2}$.

\begin{tabular}{|c|c|c|c|c|c|c|c|}
\hline Treatment & Duration (week) & C16:0 (\%) & C16:1 (\%) & C18:0 (\%) & C18:1 (\%) & C18:2 (\%) & C18:3 (\%) \\
\hline Control & 1 & $20.7 \pm 0.9$ & $1.7 \pm 0.1$ & $1.7 \pm 0.1$ & $1.8 \pm 0.3$ & $22.1 \pm 1.3$ & $52.1 \pm 1.5$ \\
\hline Control & 2 & $23.8 \pm 1.9$ & $1.6 \pm 0.2$ & $2.2 \pm 0.8$ & $1.6 \pm 0.2$ & $17.5 \pm 1.8$ & $53.3 \pm 2.2$ \\
\hline Control & 3 & $22.1 \pm 1.3$ & $2.1 \pm 0.1$ & $2.5 \pm 1.2$ & $3.3 \pm 0.8$ & $18.2 \pm 1.5$ & $51.8 \pm 2.7$ \\
\hline Control & 4 & $22.8 \pm 1.6$ & $2.3 \pm 0.1$ & $1.9 \pm 0.2$ & $2.3 \pm 0.3$ & $19.1 \pm 3.0$ & $51.7 \pm 1.7$ \\
\hline Air & 1 & $20.5 \pm 1.9$ & $1.7 \pm 0.3$ & $2.3 \pm 1.0$ & $2.1 \pm 0.8$ & $20.1 \pm 1.1$ & $53.3 \pm 3.6$ \\
\hline Air & 2 & $21.2 \pm 0.6$ & $1.8 \pm 0.1$ & $1.7 \pm 0.6$ & $1.9 \pm 0.5$ & $19.0 \pm 0.8$ & $54.4 \pm 1.1$ \\
\hline Air & 3 & $24.2 \pm 1.3$ & $1.6 \pm 0.3$ & $3.3 \pm 1.7$ & $3.1 \pm 1.5$ & $15.8 \pm 1.7$ & $51.9 \pm 3.2$ \\
\hline Air & 4 & $26.7 \pm 1.5$ & $1.6 \pm 0.1$ & $1.9 \pm 0.1$ & $1.2 \pm 0.2$ & $13.2 \pm 0.9$ & $55.4 \pm 1.2$ \\
\hline
\end{tabular}

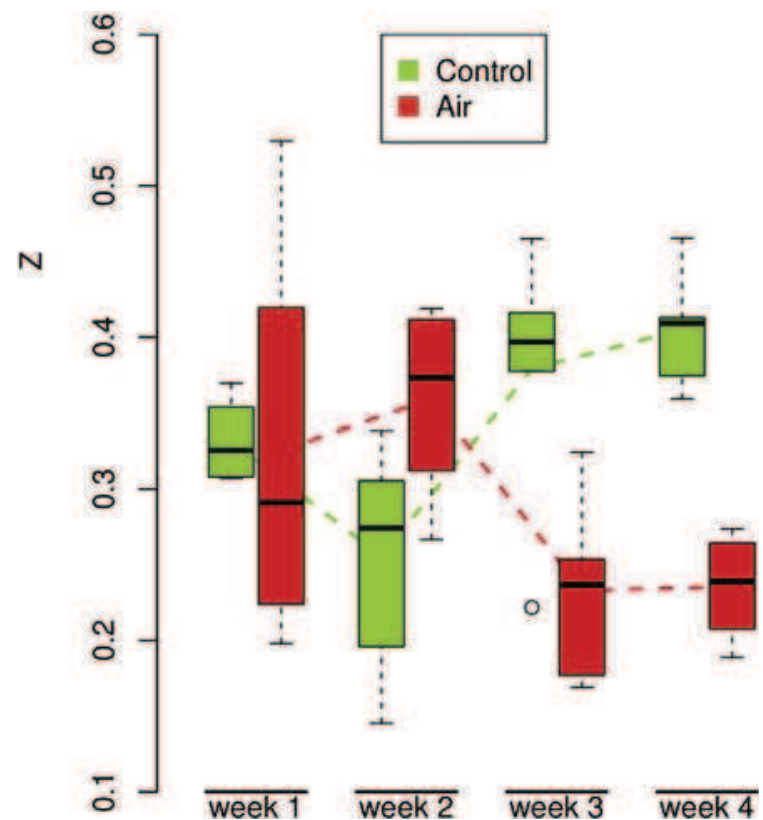

Fig. 4. Box-and-whisker plots of $\mathrm{Z}$ across treatments for air-plant exposure in $E_{2}$ experiment.

highlighting differences in air quality near a factory, and, the fatty acid composition seems to be a sensitive but also a reversible parameter. Nevertheless, no significant correlation could be highlighted between metal concentrations in plant leaves and $Z$ values (results not shown): $\mathrm{Z}$ parameter is only a qualitative marker of effect of metal pollution.

\section{Conclusions and perspectives}

This study opens up the answers to the three main issues which were raised in the introduction part. We evidenced that, as root transfer, foliar transfer also impacts fatty acid composition, that the two transfers have different effects and that they do not interact. Statistical analyses have allowed us to construct a new index, denoted $Z$, in the form of the weighted product of ratios of concentrations of the pairs of fatty acids directly involved in the mechanisms described above. This index efficiently discriminates soil-plant and/or air-plant field exposures to a complex mixture of process particles enriched with metal(loid)s. This study illustrates that the synergistic combination of statistical and ecotoxicological approaches provide new insights for understanding the mechanisms involved in metal(loid) uptake by plants and phytoxicity. Thus, further studies such as microscopy, spectroscopy and isotope fractionation are actually in progress to explore the additional implication of biotic (e.g. plant species) and abiotic (exposure duration, pedoclimatic conditions, metal speciation) factors on uptake and phytotoxicity.

\section{Acknowledgements}

We gratefully acknowledge ADEME, the French Agency of Environment and Energy for funding the DIMENSION project, as well as STCM, Chemical Metal Treatments Company for its technical help in experimental set-up and financial support.

\section{Appendix A. Supplementary data}

Supplementary data related to this article can be found at http:// dx.doi.org/10.1016/j.envpol.2013.04.024.

\section{References}

AFNOR, 2012. In: Standard X31 233, Quality of Soil, Contaminated Soil Effects on Fatty Acid Composition of Lactuca Sativa Leaves. AFNOR, Paris.

Ait Ali, N., Ater, M., Sunahara, G.I., Robidoux, P.Y., 2004. Phytotoxicity and bioaccumulation of copper and chromium using barley (Hordeum vulgare L.) in spiked artificial and natural forest soils. Ecotoxicology and Environmental Safety $57,363-374$.

Alexander, P.D., Alloway, B.J., Dourado, A.M., 2006. Genotypic variations in the accumulation of $\mathrm{Cd}, \mathrm{Cu}, \mathrm{Pb}$ and $\mathrm{Zn}$ exhibited by six commonly grown vegetables. Environmental Pollution 144, 736-745.

Aronsson, H., Schöttler, M.A., Kelly, A.A., Sundqvist, C., Dörmann, P., Karim, S., Jarvis, P., 2008. Monogalactosyldiacylglycerol deficiency in Arabidopsis affects pigment composition in the prolamellar body and impairs thylakoid membrane energization and photoprotection in leaves. Plant Physiology 148, 580-592.

Ben Youssef, N., Nouairi, I., Ben Temime, S., Taamalli, W., Zarrouk, M., Ghorbal, M.H., Ben Miled Daoud, D., 2005. Cadmium effects on lipid metabolism of rape (Brassica napus L.). Comptes-rendus de Biologie 328, 745-757.

Bermudez, G.M.A., Jasan, R., Plá, R.R., Pignata, M.L., 2011. Heavy metal and trace element concentrations in wheat grains: assessment of potential noncarcinogenic health hazard through their consumption. Journal of Hazardous Materials 193, 264-271.

Bermudez, G.M.A., Jasan, R., Plá, R.R., Pignata, M.L., 2012. Heavy metals and trace elements in atmospheric fall-out: their relationship with topsoil and wheat element composition. Journal of Hazardous Materials 213-214, 447-456.

Birbaum, K., Brogiolo, R., Schellenberg, M., Martinoia, E., Stark, W.J., Günther, D., Limbach, L., 2010. No evidence for cerium dioxide nanoparticle translocation in maize plants. Environmental Science and Technology 44, 8718-8723.

Box, G.E.P., Cox, D.R., 1964. An analysis of transformations. Journal of the Royal Statistical Society Series B 26, 211-252.

Bravin, M.N., Michaud, A.M., Larabi, B., Hinsinger, P., 2010. RHIZOtest: a plant-based biotest to account for rhizosphere processes when assessing copper bioavailability. Environmental Pollution 158, 3330-3337.

Chamberlain, A.C., 1983. Fallout of lead and uptake by crops. Atmospheric Environment 17, 693-706.

Cipak, A., Hasslacher, M., Tehlivets, O., Collinson, E.J., Zivkovic, M., Matijevic, T., Wonisch, I., Waeg, G., Dawes, I.W., Zarkovic, N., Kohlwein, S.D., 2006. Saccharomyces cerevisiae strain expressing a plant fatty acid desaturase produces polyunsaturated fatty acids and is susceptible to oxidative stress induced by lipid peroxidation. Free Radical Biology and Medicine 40, 897-906.

Cipak, A., Jaganjac, M., Tehlivets, O., Kohlwein, S.D., Zarkovic, N., 2008. Adaptation to oxidative stress induced by polyunsaturated fatty acids in yeast. Biochimica and Biophysica Acta (BBA) - Molecular and Cell Biology of Lipids 1781, 283-287.

Djebali, W., Zarrouk, M., Brouquisse, R., El Kahoui, S., Limam, F., Ghorbel, M.H., Chaibi, W., 2005. Ultrastructure and lipid alterations induced by cadmium in tomato (Lycopersicon esculentum) chloroplast membranes. Plant Biology 7, 358-368.

Dmuchowski, W., Gozdowski, D., Baczewska, A.H., 2011. Comparison of four bioindication methods for assessing the degree of environmental lead and cadmium pollution. Journal of Hazardous Materials 197, 109-118. 
Donisa, C., Mocanu, R., Steinnes, E., Vasu, A., 2000. Heavy metal pollution by atmospheric transport in natural soils from the northern part of eastern Carpathians. Water, Air and Soil Pollution 120, 347-358.

Foucault, Y., Durand, M.J., Tack, K., Schreck, E., Geret, F., Leveque, T., Pradere, P., Goix, S., Dumat, C., 2013. Use of ecotoxicity test and ecoscores to improve the management of polluted soils: case of a secondary lead smelter plant. Journal of Hazardous Materials 246-247, 291-299.

Gandois, L., Tipping, E., Dumat, C., Probst, A., 2010. Canopy influence on trace metal atmospheric inputs on forest ecosystems: speciation in throughfall. Atmospheric Environment 44, 824-833.

Hu, X., Zhang, Y., Luo, J., Xie, M., Wang, T., Lian, H., 2011. Accumulation and quantitative estimates of airborne lead for a wild plant (Aster subulatus). Chemosphere 82, 1351-1357.

Isaure, M.P., Fayard, B., Sarret, G., Pairis, S., Bourguignon, J., 2006. Localization and chemical forms of cadmium in plant samples by combining analytical electron microscopy and X-ray spectromicroscopy. Spectrochimica Acta Part B: Atomic Spectroscopy 61 (12), 1242-1252.

Ivanov, A.G., Allakhverdiev, S.I., Huner, N.P.A., Murata, N., 2012. Genetic decrease in fatty acid unsaturation of phosphatidylglycerol increased photoinhibition of photosystem I at low temperature in tobacco leaves. Biochimica and Biophysica Acta $1817,1374-1379$.

Jemal, F., Zarrouk, M., Ghorbal, M.H., 2000. Effect of Cadmium on Lipid Composition of Pepper. In: 14th International Symposium on Plant Lipids held at Cardiff University, 23-28 July 2000 in: Biochemistry Society Transactions vol. 28, pp. 907-910.

Kobayashi, K., Kondo, M., Fukuda, H., Nishimura, M., Ohta, H., 2007. Galactolipid synthesis in chloroplast inner envelope is essential for proper thylakoid biogenesis, photosynthesis, and embryogenesis. Proceedings of the National Academy of Sciences of the United States of America 104, 17216-17221.

Komárek, M., Vanek, A., Ettler, V., 2013. Chemical stabilization of metals and arsenic in contaminated soils using oxides. Environmental Pollution 172, 9-22.

Kutner, M.H., Nachtsheim, C.J., Neter, J., Li, W., 2004. Applied Linear Statistical Models, fifth ed. McGraw-Hill Irwin, New-York

Lebeda, A., Ryder, E.J., Grube, R., Doležalová, I., Křístková, E., 2007. Lettuce (Asteraceae; Lactuca spp.). In: Singh, R.J. (Ed.), Genetic Resources, Chromosome Engineering, and Crop Improvement. Vegetable Crops, vol. 3. CRC Press, Tailor and Francis Group, Boca Raton, pp. 377-472.

Le Guédard, M., Schraauwers, B., Larrieu, I., Bessoule, J.J., 2008. Development of a biomarker for metal bioavailability: the lettuce fatty acid composition. Environmental Toxicology and Chemistry 27, 1147-1151.

Le Guédard, M., Faure, O., Bessoule, J.J., 2012a. Soundness of in situ lipid biomarker analysis: early effect of heavy metals on leaf fatty acid composition of Lactuca serriola. Environmental and Experimental Botany 76, 54-59.

Le Guédard, M., Faure, O., Bessoule, J.J., 2012b. Early changes in the fatty acid composition of photosynthetic membrane lipids from Populus nigra grown on a metallurgical landfill. Chemosphere 88, 693-698.

Li, X., Zhao, M., Guo, L., Huang, L., 2012. Effect of cadmium on photosynthetic pigments, lipid peroxidation, antioxidants, and artemisinin in hydroponically grown Artemisia annua. Journal of Environmental Sciences 24, 1511-1518.

Lin, D., Xing, B., 2007. Phytotoxicity of nanoparticles: inhibition of seed germination and root growth. Environmental Pollution 150, 243-250.

Lin, D., Xing, B., 2008. Root uptake and phytotoxicity of ZnO nanoparticles. Environmental Science and Technology 42, 5580-5585.

Lombi, E., Scheckel, K.G., Kempsond, I.M., 2011. In situ analysis of metal(loid)s in plants: state of the art and artefacts. Environmental and Experimental Botany $72,3-17$.

Ma, X., Geiser-Lee, J., Deng, Y., Kolmakov, A., 2010. Interactions between engineered nanoparticles (ENPs) and plants: phytotoxicity, uptake and accumulation. Science of the Total Environment 16, 3053-3061.

Nair, R., Varghese, S., Nair, B., Maekawa, T., Yoshida, Y., Kumar, D., 2010. Nanoparticulate material delivery to plants. Plant Science 179, 154-163.

NF EN 14902, December 2005. Qualité de l'air ambiant - Méthode normalisée pour la mesure du plomb, cadmium, de l'arsenic et du nickel dans la fraction MP10 de la matière particulaire en suspension.
Ouariti, O., Boussama, N., Zarrouk, M., Cherif, A., Ghorbal, M.H., 1997. Cadmiumand copper-induced changes in tomato membrane lipids. Phytochemistry 45 , 1343-1350.

Pereira, R., Marques, C.R., Silva Ferreira, M.J., Neves, M.F.J.V., Caetano, A.L., Antunes, S.C., Mendo, S., Gonçalves, F., 2009. Phytotoxicity and genotoxicity of soils from an abandoned uranium mine area. Applied Soil Ecology 42, 209-220.

Perrone, M.G., Gualtieri, M., Ferrero, L., Lo Porto, C., Udisti, R., Bolzacchini, E., Camatini, M., 2010. Seasonal variations in chemical composition and in vitro biological effects of fine PM from Milan. Chemosphere 78, 1368-1377.

Polichetti, G., Cocco, S., Spinali, A., Trimarco, V., Nunziata, A., 2009. Effects of particulate matter $\left(\mathrm{PM}_{10}, \mathrm{PM}_{2.5}\right.$ and $\left.\mathrm{PM}_{1}\right)$ on the cardiovascular system. Toxicology 261, 1-8.

R Core Team, 2012. R: a Language and Environment for Statistical Computing, ISBN 3 900051-07-0.

Sanitá di Toppi, L., Gabbrielli, R., 1999. Response to cadmium in higher plants. Environmental and Experimental Botany 41, 105-130.

Schreck, E., Foucault, Y., Geret, F., Pradere, P., Dumat, C., 2011. Influence of soil ageing on bioavailability and ecotoxicity of lead carried by process waste metallic ultrafine particles. Chemosphere 85, 1555-1562.

Schreck, E., Foucault, Y., Sarret, G., Sobanska, S., Cécillon, L., Castrec-Rouelle, M., Uzu, G., Dumat, C., 2012a. Metal and metalloid foliar uptake by various plant species exposed to atmospheric industrial fallout: mechanisms involved for lead. Science of the Total Environment 427-428, 253-262.

Schreck, E., Bonnard, R., Laplanche, C., Leveque, T., Foucault, Y., Dumat, C., 2012b. DECA: a new model for assessing the foliar uptake of atmospheric lead by vegetation, using Lactuca sativa as an example. Journal of Environmental Management 112, 233-239.

Serbula, S.M., Miljkovic, D., Kovacevic, R., Ilic, A., 2012. Assessment of air borne heavy metal pollution using plant parts and topsoil. Ecotoxicology and Environmental Safety 76, 209-214.

Stampoulis, D., Sinha, S.K., White, J.C., 2009. Assay-dependent phytotoxicity of nanoparticles to plants. Environental Science and Technology 43, 9473-9479.

Straczek, A., Sarret, G., Manceau, A., Hinsinger, P., Geoffroy, N., Jaillard, B., 2008. Zinc distribution and speciation in roots of various genotypes of tobacco exposed to Zn. Environmental and Experimental Botany 63, 80-90.

Taylor, F.G., Witherspoon, J.P., 1972. Retention of simulated fallout particles by lichens and mosses. Health Physiology 23, 867-876.

Upchurch, R.G., 2008. Fatty acid unsaturation, mobilization, and regulation in the response of plants to stress. Biotechnology Letters 30, 967-977.

Uzu, G., Sobanska, S., Aliouane, Y., Pradere, P., Dumat, C., 2009. Study of lead phytoavailability for atmospheric industrial micronic and sub-micronic particles in relation with lead speciation. Environmental Pollution 157, 1178-1185.

Uzu, G., Sobanska, S., Sarret, G., Munoz, M., Dumat, C., 2010. Foliar lead uptake by lettuce exposed to atmospheric fallouts. Environmental Science and Technology $44,1036-1042$.

Uzu, G., Sobanska, S., Sarret, G., Sauvain, J.J., Pradère, P., Dumat, C., 2011. Characterization of lead-recycling facility emissions at various workplaces: major insights for sanitary risk assessment. Journal of Hazardous Materials 186, 1018-1027.

Venables, W.N., Ripley, B.D., 2010. Modern Applied Statistics with S, fourth ed. Springer-Verlag, New York.

Violante, A., Cozzolino, V., Perelomov, L., Caporale, A.G., Pigna, M., 2010. Mobility and bioavailability of heavy metals and metalloids in soil environments. Journal of Soil Science and Plant Nutrition 10, 268-292.

Waisberg, M., Black, W.D., Waisberg, C.M., Hale, B., 2004. The effect of pH, time and dietary source of cadmium on the bioaccessibility and adsorption of cadmium to/from lettuce (Lactuca sativa L. cv. Ostinata). Food and Chemical Toxicology 42, $835-842$.

Ward, N.I., Savage, J.M., 1994. Metal dispersion and transportational activities using foog crops as biomonitors. Science of the Total Environment 146-147, 309-319.

Yin, L., Cheng, Y., Espinasse, B., Colman, B.P., Auffan, M., Wiesner, M., Rose, J., Liu, J., Bernhardt, E.S., 2011. More than the ions: the effects of silver nanoparticles on Lolium multiflorum. Environmental Science and Technology 45, 2360-2367. 